\title{
Reckoning with Asian America
}

\author{
Jennifer Lee and Tiffany Huang \\ Jennifer Lee is the Julian Clarence Levi Professor of Social Science in the Department of Sociology at Columbia University, New York, NY, USA. lee.jennifer@columbia.edu \\ Tiffany Huang is a graduate student in the Department of Sociology at Columbia University, New York, NY, USA. tjh2150@columbia.edu
}

It took the mass murder of six Asian women in Atlanta last week to draw national attention to what Asian Americans have been warning about since the wake of the pandemicanti-Asian violence. The incident reflects an under-recognized history of anti-Asian violence and discrimination in this country that dates back more than 150 years. This needs to change. Asian Americans must become central to the discourse on race in America. For the country to "care" about the outcry by Asian Americans, the public needs to understand how America got to this point.

This moment of crisis has been building over the past pandemic year. Many consider the recent anti-Asian violence and harassment a consequence of the former Trump administration's "China virus" and "Kung flu" rhetoric. Research shows that Americans exposed to such racist rhetoric are more likely to perceive Asian Americans as foreign and un-American, which can stoke greater hostility toward Asians. Last summer, three in four Asian Americans expressed worry about COVID-19-related hate crimes. Nearly 3800 incidents of antiAsian hate have been reported to Stop AAPI Hate, ranging from verbal harassment to physical assault. The most vulnerable have been the most convenient targets: Asian women (who report three times as many incidents as Asian men); older adults; and low-wage employees, such as the victims in Atlanta.

U.S. history is fraught with anti-Asian violence, misogyny, nativist discrimination, and legal exclusion, all of which are often absent in textbooks and university curricula. The 1882 Chinese Exclusion Act emerged from the earlier Page Act, which excluded presumed immoral Chinese women from immigrating. Without their wives, male Chinese laborers who helped build the transcontinental railroad segregated into tight-knit bachelor communities that became the precursors of today's Chinatowns. Legal exclusion was coupled with violence. One of the largest mass lynchings in American history took place in Los Angeles in 1871, when 19 Chinese residents $-10 \%$ of the city's Chinese population-were killed by a white mob. In the Rock Springs Massacre of 1885, white miners killed 28 Chinese workers, wounded 15, and expelled hundreds more before setting their living quarters on fire.

The nativist prejudice that white settlers imparted, and the legal exclusion that Chinese endured, engineered the very conditions that would shape societal perceptions of the Chinese in the 19th century as economic threats, clannish, untrustworthy, foreign, and immoral. These views would continue to mark Chinese Americans and evolve into the racial stereotypes of Asian Americans today-untrustworthy, passive, demure, hypersexual, and America's insidious "model minority."

Academia has not been immune to the effects of this history on institutional racism, bias, exclusion, and violence. COVID-19-related anti-Asian messages and harassment have been reported on college campuses across the country. Chinese American scientists have come under federal scrutiny for their associations with China under the 2018 China Initiative, which may jeopardize U.S.-Chinese scientific collaborations. And despite being the group most likely to attend college, Asian Americans make up a mere 2\% of college presidents. Asian Americans are the least likely among all women to be promoted to leadership positions, and make up less than $1 \%$ of top earners at those universities engaging in the highest level of research activity. Anti-Asian bias also affects students. In one study, researchers sent emails with names signaling race and gender to 6548 professors, posing as prospective PhD students. Professors were the least likely to respond to those who had Chinese and Indian names.

If universities and precollege schools fail to teach the history of Asian Americans in their curricula, we can expect bias and exclusion to perpetuate in our institutions. Asian American student activists in the 1960s understood this. They coined the term "Asian American" as a unifying political, panethnic identity to advocate for Asian American Studies and build coalitions with African Americans, Latino/as, and women. Many Americans are unaware of this history, including Asian Americans, most of whom are immigrants who arrived after 1965. Today, Asian Americans encompass more than two dozen national origin groups with vastly different migration histories, languages, and socioeconomic statuses. Yet during the pandemic, they have shared a common fear of harassment, discrimination, and anti-Asian violence.

Violence and bigotry against Asian Americans have finally received national attention. We must make Asian Americans central to the country's discussions of race, and reckon with the history of Asian America.

Published online 25 March 2021 10.1126/science.abi6877 